\title{
Age-dependent synuclein pathology following traumatic brain injury in mice
}

\author{
K. Uryu, ${ }^{\text {a }}$ B.I. Giasson, ${ }^{a}$ L. Longhi, ${ }^{b}$ D. Martinez, ${ }^{a}$ I. Murray, ${ }^{a}$ V. Conte, ${ }^{b}$ M. Nakamura, ${ }^{b}$ \\ K. Saatman, ${ }^{b}$ K. Talbot, ${ }^{c}$ T. Horiguchi, ${ }^{a}$ T. McIntosh, ${ }^{b}$ V.M.-Y. Lee, ${ }^{a}$ \\ and J.Q. Trojanowski ${ }^{\mathrm{a}, \mathrm{d}, *}$ \\ ${ }^{a}$ The Center for Neurodegenerative Disease Research, Department of Pathology and Laboratory Medicine, University of Pennsylvania \\ School of Medicine, Philadelphia, PA, USA \\ ${ }^{\mathrm{b}}$ Head Injury Center, Department of Neurosurgery, University of Pennsylvania School of Medicine, Philadelphia, PA, USA \\ ${ }^{\mathrm{c}}$ Head Injury Center, Department of Psychiatry, University of Pennsylvania School of Medicine, Philadelphia, PA, USA \\ ${ }^{\mathrm{d}}$ The Institute on Aging, University of Pennsylvania School of Medicine, Philadelphia, PA, USA
}

Received 4 March 2003; revised 9 April 2003; accepted 16 April 2003

\begin{abstract}
Synucleins (Syn), a family of synaptic proteins, includes $\alpha$-Syn, which plays a pivotal role in Parkinson's disease and related neurodegenerative diseases (synucleinopathies) by forming distinct brain pathologies (Lewy bodies and neurites). Since traumatic brain injury (TBI) is a poorly understood risk factor for Parkinson's disease, we examined the effects of TBI in the young and aged mouse brain on $\alpha$-, $\beta$-, and $\gamma$-Syn. Immunohistochemical analysis showed that brains from sham-injured young and aged mice had normal $\alpha$ - and $\beta$-Syn immunoreactivity (IR) in neuropil of cortex, striatum, and hippocampus with little or no $\gamma$-Syn IR. At 1 week post TBI, the aged mouse brain showed a transient increase of $\alpha$ - and $\beta$-Syn IR in the neuropil as well as an induction of $\gamma$-Syn IR in subcortical axons. This was associated with strong labeling of striatal axon bundles by antibodies to altered or nitrated epitopes in $\alpha$-Syn as well as by antibodies to inducible nitric oxide synthase. However, these TBI-induced changes disappeared by 16 weeks post TBI, and altered Syn IR was not seen in young mice subjected to TBI nor in $\alpha$-Syn knockout mice while Western blots confirmed that TBI induced transient alterations of $\alpha$-Syn in the mouse brains. This model of age-dependent TBI-induced transient alterations in $\alpha$-Syn provides an opportunity to examine possible links between TBI and mechanisms of disease in synucleinopathies.
\end{abstract}

(C) 2003 Elsevier Science (USA). All rights reserved.

Keywords: Traumatic brain injury; Mouse brain; Neurodegenerative disease; Synuclein

\section{Introduction}

Synuclein (Syn) proteins are directly implicated in human diseases since $\alpha$-Syn gene mutations have been identified in rare kindreds with familial Parkinson's disease (PD) (Polymeropoulos et al., 1997; Kruger et al., 1998), and $\alpha$-Syn inclusions occur in hereditary and sporadic PD

* Corresponding author: Center for Neurodegenerative Disease Research, Department of Pathology and Laboratory Medicine, University of Pennsylvania School of Medicine, HUP/Maloney 3rd Floor, Philadelphia, PA 19104-4283, USA. Fax: +1-215-349-5909.

E-mail address: trojanow@mail.med.upenn.edu (J.Q. Trojanowski).
(Arima et al., 1998; Tu et al., 1998; Arawaka et al., 1998; Spillantini et al., 1997, 1998; Irizarry et al., 1998; Baba et al., 1998; Duda et al., 2002). Previous studies have shown that $\alpha$-Syn is the primary building block of filamentous Lewy bodies (LBs) and dystrophic Lewy neurites in PD and related disorders known as synucleinopathies (Baba et al., 1998; Giasson et al., 2000b). In addition, $\alpha$-Syn forms filaments in vitro and $\alpha$-Syn transgenic animals develop LB-like inclusions associated with neurodegeneration (Auluck et al., 2002; Conway et al., 1998; Feany and Bender 2000; Masliah et al., 2000; Giasson et al., 2000a; Paxinou et al., 2001). Moreover, $\alpha$-Syn in human synucleinopathy brains is pathologically altered by ubiquitination, phosphor- 
Table 1

List of antibodies

\begin{tabular}{|c|c|c|c|c|}
\hline Antibodies & Epitope/antigen & Dilution & Species & Reference \\
\hline Syn202 & $\alpha$ - and $\beta$-Syn & $1: 20 \mathrm{~K}$ & Mouse & Giasson et al., 2000b \\
\hline SNL-1 & $\alpha$-Syn (104-119) & $1: 5 \mathrm{~K}$ & Rabbit & Giasson et al., 2000b \\
\hline Syn207 & $\beta$-Syn & $1: 20 \mathrm{~K}$ & Rabbit & Giasson et al., 2000b \\
\hline$\beta-2$ & $\beta$-Syn & $1: 2 \mathrm{~K}$ & Rabbit & This study \\
\hline Syn102 & $\alpha-, \beta$-Syn, C-terminus (130-140) & $1: 1 \mathrm{~K}$ & Mouse & Giasson et al., 2000b \\
\hline Syn119 & $\alpha$-Syn, NAC & $1: 1 \mathrm{~K}$ & Mouse & This study \\
\hline Syn205 & $\alpha-, \beta$-Syn, C-terminus (130-140) & $1: 1 \mathrm{~K}$ & Mouse & Giasson et al., 2000b \\
\hline Syn214 & $\alpha-, \beta$-Syn, C-terminus (130-140) & $1: 1 \mathrm{~K}$ & Mouse & Giasson et al., 2000b \\
\hline Syn303 & Conformational $\alpha->\beta->\gamma-\operatorname{Syn}(\alpha-\operatorname{Syn} N$-terminus $)$ & $1: 500$ & Mouse & Duda et al., 2002 \\
\hline Syn505 & Conformational $\alpha->\beta->\gamma$-Syn ( $\alpha$-Syn $N$-terminus) & $1: 500$ & Mouse & Duda et al., 2002 \\
\hline Syn506 & Conformational $\alpha->\beta->\gamma$-Syn $(\alpha-$ Syn $N$-terminus $)$ & $1: 500$ & Mouse & Duda et al., 2002 \\
\hline Syn514 & Conformational $\alpha->\beta->\gamma$-Syn ( $\alpha$-Syn N-terminus) & $1: 500$ & Mouse & Duda et al., 2002 \\
\hline$\gamma-1$ & $\gamma$-Syn & $1: 1 \mathrm{~K}$ & Mouse & Giasson et al., 2001 \\
\hline nSyn14 & Nitrated $\alpha$-Syn & Neat & Mouse & Giasson et al., 2000a \\
\hline iNOS-2 & INOS & $1: 50$ & Rabbit & Santa Cruz Biotech \\
\hline LN-39 & APP & $1: 50$ & Mouse & Nakagawa et al., 2000 \\
\hline NFL & NFL & $1: 2 \mathrm{k}$ & Rabbit & Ishihara et al., 1999 \\
\hline
\end{tabular}

ylation, nitration, and conformational modifications (Duda et al., 2002; Giasson et al., 2000a; Fujiwara et al., 2002).

Mechanistic insights into disease processes underlying PD and related disorders have evolved substantially since the link between these diseases and $\alpha$-Syn pathology was discovered, but it is not yet known how normal $\alpha$-Syn is transformed from a highly soluble synaptic protein into filamentous perikaryal aggregates in the disease state (Trojanowski and Lee., 2002). Although the genetic determinants of late-onset PD are uncertain (Tanner et al., 1999), traumatic brain injury (TBI) has been identified as an environmental risk factor for sporadic PD (Nayernouri, 1985; Factor and Weiner, 1991; Stern, 1991), in addition to exposure to neurotoxins (Langston et al., 1983; Hubble et al., 1993; Przedborski and Jackson-Lewis, 1998; Betarbet et al., 2000). Although the brains of patients with dementia pugilistica are characterized by plaques and tangles similar to those seen in Alzheimer's disease (AD), the abnormal accumulation of $\alpha$-Syn in axonal swellings and dystrophic neurites in these brains suggests a possible link between TBI and the development of $\alpha$-Syn pathology in PD (Newell et al., 1999), which could be mediated by TBI-induced oxidative and nitrative stress (Mesenge et al., 1988). Indeed, experimental TBI has been shown to cause oxidative stress in wild-type (WT) mice (Pratico et al., 2002) and in Tg mouse models (Tg2576) of AD-like amylodosis (Uryu et al., 2002). Further, TBI-induced oxidative stress was associated with an augmentation of $A \beta$ levels and deposits in the brains of Tg2576 mice (Uryu et al., 1993). Thus, emerging data indicate that TBI causes chronic as well as acute neurodegeneration (Maxwell et al., 1997; McIntosh et al., 1998; Uryu et al., 2002). Nonetheless, experimental evidence directly linking TBI to the development of $\alpha$-Syn pathology or any other abnormalities in PD and related disorders has not been obtained.

Thus, we addressed this issue by examining the effects of
TBI on the expression of $\alpha-, \beta$-, and $\gamma$-Syn in WT mice subjected to controlled cortical impact (CCI) injury, and our studies revealed that TBI induces transient nitrative alterations in $\alpha$-Syn similar to those seen in PD and related synucleinopathies.

\section{Materials and methods}

\section{Antibodies}

The panel of antibodies to $\alpha-, \beta-$, and $\gamma$-Syn as well as to other proteins studied here in summarized in Table 1 together with the provenance and citations on the characterization and properties of these antibodies.

\section{Animals and injury}

The CCI paradigm for TBI was applied to 4-month-old (young) $(n=35)$ and 24-month-old (aged) WT mice ( $n=$ 25 ) with (B6D2F1 background) and to 16-month-old $\alpha$-Syn knockout $(\mathrm{KO})$ mice $(n=6$; kindly provided by Dr. Asa Abeliovich) (Abeliovich et al., 2000). The procedures for CCI have been described in detail elsewhere (Murai et al., 1998; Nakagawa et al., 1999, 2000). Briefly, an anesthetized mouse was mounted on the stereotactic frame, the scalp and temporal muscle were reflected, and 5-mm craniectomy was performed (centered between the lambda and bregma over the left parietal cortex) with the dura remaining intact. CCI brain injury was produced as modified from the original paradigm described by Dixon et al. (1991) by using a 3-mm metal impounder driven at a velocity of $5.0 \mathrm{~m} / \mathrm{s}$ to a depth of $1.0 \mathrm{~mm}$ over a time frame of $100 \mathrm{~ms}$ as described (Murai et al., 1998; Nakagawa et al., 1999, 2000). A transducer attached to the device provided an analog signal recorded by a computer program (R.C. Electronics, Santa Barbara, CA) 
for monitoring impact parameters. Uninjured control mice were surgically prepared in a similar manner, but they were not subjected to CCI injury. After CCI brain injury, the craniotomy was covered with a cranioplasty and the scalp was sutured. All mice were allowed to recover on a heating pad maintained at $37^{\circ} \mathrm{C}$.

Sham and CCI mice were allowed to survive for various time periods, as follows: young mice for 1, 3, 5 days, and 1 , 9, and 16 weeks post injury, aged mice for 1,9 , and 16 weeks post injury, and aged $\alpha$-Syn KO mice for 1 week. All of these procedures were performed in strict accordance with the National Institutes of Health Guide for the Care and Use of Laboratory Animals (National Research Council, 1996) and they were approved by the Institutional Animal Care and Use Committee of the University of Pennsylvania.

\section{Immunohistochemistry}

For immunohistochemical analyses, animals were deeply anesthetized and were perfused with saline followed by $10 \%$ neutral buffered formalin (NBF). The brain was removed and fixed overnight with fresh $10 \% \mathrm{NBF}$, embedded in paraffin, and a series of 6- $\mu \mathrm{m}$ sections were cut for immunohistochemistry (IHC) with and without the use of antigen retrieval procedures as described (Uryu et al., 2002; Murai et al., 1998; Nakagawa et al., 1999, 2000). Sections from some mouse brains were pretreated prior to IHC with anti-mouse IgG Fab (30 $\mu \mathrm{l} / \mathrm{ml}$ ) (Jackson ImmunoResearch Lab, Inc.) in donor horse serum (DHS) for $30 \mathrm{~min}$ to eliminate background due to residual endogenous mouse IgG. Sections were incubated with primary antibodies (see Table 1) overnight and with an appropriate biotinylated secondary antibody for $1 \mathrm{~h}$. The avidin-biotin complex method was used according to instructions of the vendor (Vector Lab, Inc.) with 3,3'-diaminobenzidine as chromogen. The sections were counterstained with hematoxylin, dehydrated in series of ethanol, cleared in xylene, and coverslipped with paramount.

Colocalization of $\alpha$-Syn with neurofilament (NF) subunits, or with $\mathrm{A} \beta$ precursor proteins (APP), was examined by applying double fluorescence IHC (FIHC). For Syn303 to $\alpha$-Syn and the rabbit antiserum NFL to the low $\mathrm{M}_{\mathrm{r}} \mathrm{NF}$ subunit (NFL), double FIHC was performed by incubating sections with a mixture of the mouse monoclonal antibody (mAb) Syn303 and polyclonal NFL antiserum overnight and subsequently done with a mixture of Alexa 488-antimouse IgG and Alexa 594-anti-rabbit IgG (Molecular Probes, Inc.) for $2 \mathrm{~h}$. For double FIHC using mAb Syn303 and mouse mAb LN-39 to APP, single FIHC was conducted with Syn303, which was visualized with Alexa 488-antimouse $\operatorname{IgG}$ followed by blocking sections with anti-mouse IgG Fab in DHS (30 min). Subsequently, another round of single FIHC was carried out by using the LN-39 mAb, which was visualized by Alexa 594-anti-mouse IgG. Then, the sections were treated with $3 \%$ of Sudan Black for 10 min (Romijn et al., 1999) to suppress autofluorescence and mounted with Vectashield mounting medium with 4,6-diamidino-2-phenylindole (Vector Laboratories).

For all of IHC experiments, negative controls included the application of the same IHC protocols to sections using preimmune serum or DHS instead of primary antibody. Analysis of stained sections was done by bright-field and fluorescence microscopy by using an Olympus BX51 attached to a CCD camera (ProgResC14, Jenoptic Camera Europe Inc., Jena, Germany).

\section{Western blot studies}

For sequential biochemical fractionation and Western blot studies of $\alpha$-Syn, selected unfixed brains were removed and frozen with dry ice powder. Cortical and subcortical regions subjacent to the impact site were excised from the left hemisphere of the CCI mice and equivalent areas from the right hemisphere also were excised for parallel studies as controls. Each sample was weighed and homogenized in $3 \mathrm{ml} / \mathrm{g}$ of high salt (HS) buffer $(50 \mathrm{mM}$ Tris, $\mathrm{pH} 7.5,750$ $\mathrm{mM} \mathrm{NaCl}, 5 \mathrm{mM}$ EDTA) and a cocktail of protease inhibitors $(1 \mathrm{mM}$ phenylmethylsulfonyl and $1 \mathrm{mg} / \mathrm{ml}$ each of pepstatin, leupeptin, $N$-tosyl-L-phenylalanyl chloromethyl ketone, $\mathrm{N}$-tosyl-lysine chloromethyl ketone, and soybean trypsin inhibitor). The samples were sedimented at 100,000 $\times g$ for 20 min each. Pellets were reextracted with HS buffer followed by two sequential extractions with $3 \mathrm{ml} / \mathrm{g}$ of HS buffer containing $1 \%$ Triton X-100 (HS/T fraction). The pellets were homogenized in $500 \mathrm{ml}$ of $\mathrm{HS}$ buffer/1 M sucrose and after centrifugation the floating myelin was discarded. The pellets were extracted with $2 \mathrm{ml} / \mathrm{g}$ of RIPA [50 mM Tris, pH 8.0, $150 \mathrm{mM} \mathrm{NaCl}, 5 \mathrm{mM}$ EDTA, $1 \%$ NP40, $0.5 \%$ sodium deoxycholate, $0.1 \%$ sodium dodecyl sulfate (SDS)] and sedimented at $100,000 \times g$ for $20 \mathrm{~min}$. Half of each pelleted sample was extracted with $1 \mathrm{ml} / \mathrm{g}$ SDS-sample buffer (SDS fraction) by sonication and heating to $100^{\circ} \mathrm{C}$ for $10 \mathrm{~min}$ in or $70 \%$ formic acids (FA fraction) by sonication. FA was removed by lyophilization and the dried material was resuspended in $1 \mathrm{ml} / \mathrm{g}$ of SDSsample buffer by heating to $100^{\circ} \mathrm{C}$ for $10 \mathrm{~min}$. Five microliters of each fraction was loaded on separate lanes of 13\% polyacrylamide gels. Proteins were resolved on slab gels by SDS-polyacrylamide gel electrophoresis (SDS-PAGE) and electrophoretically transferred onto nitrocellulose membranes (Schleicher and Schuell, Keene, NH) in buffer containing $48 \mathrm{mM}$ Tris, $39 \mathrm{mM}$ glycine, and $10 \%$ methanol. Membranes were blocked with a 5\% solution of powdered milk dissolved in Tris-buffered saline-Tween $(50 \mathrm{mM}$ Tris, $\mathrm{pH}$ 7.6, $150 \mathrm{mM} \mathrm{NaCl}, 0.1 \%$ Tween 20), incubated with primary antibodies followed with either a goat anti-mouse or rabbit IgG horseradish peroxidase (HRP)-conjugated an- 
tibody (Jackson ImmunoResearch Lab), and visualized on films using enhanced chemiluminescence reagents (NEN, Boston, MA) or directly on the membrane with 3,3'-diaminobenzidine as the chromogen.

\section{Results}

\section{Recognition of CCI-injured areas}

APP immunoreactivity (IR) was used to detect axons damaged by CCI in brain subjacent to the impact site as described (Pierce et al., 1998). In the aged mouse at 1 week post TBI, APP IR was noted exclusively in areas ipsilateral to the site of CCI, including the somatosensory and cingulate cortex, the corpus callosum, dorsolateral thalamus striatum, globus pallidus and hippocampus, especially axons in CA3 and fimbria, but the most severely affected structures were striatal and pallidal axon bundles (Fig. 1A).

\section{Transient effects of TBI on Syn IR in aged mouse brain}

Staining patterns of $\alpha-, \beta$-, and $\gamma$-Syn in normal mouse have been previously described (Giasson et al., 2001), and the brains of sham (uninjured) aged mice showed Syn IR consistent with this previous report, whereas the brains of mice subjected to CCI-induced TBI showed alterations in the distribution of $\alpha-, \beta$-, and $\gamma$-Syn confined to those areas wherein APP IR was noted in damaged axons although these alterations were not as dramatic as those revealed by antibodies to APP (Fig. 1A).

In the sham-treated mouse brains, antibodies to $\alpha$-Syn demonstrated light staining in the striatum (Fig. 1B) as well as in cortex, thalamus, and hippocampus (not shown). However, TBI induced by CCI caused a modest enhancement of $\alpha$-Syn (SNL-1) IR between 1 and 9 weeks post injury (Fig. $1 \mathrm{~A}$ and $\mathrm{B})$, especially in the neuropil of cortex, striatum, and hippocampus (e.g., fimbria and CA3 region), but this was only evident on high magnification (Fig. 1A and B). The intensity of $\alpha$-Syn IR was reduced by 16 weeks post injury to levels close to those seen in the sham-treated mice wherein no diffuse axonal injury profiles or spheroids were seen to exhibit APP IR or $\alpha$-Syn IR (Fig. 1B).

As in normal mice, $\beta$-Syn (Syn207, $\beta$-2) exhibited modest IR in the neuropil of sham-treated mice in the same brain areas wherein $\alpha$-Syn IR was located. However, the intensity of $\beta$-Syn IR was enhanced in the cortical neuropil near the area of impact, as well as in the subjacent striatum (Fig. 1A and $\mathrm{B}$ ), the hilus of the hippocampus, and the dorsolateral thalamus (not shown) 1 week following TBI in aged mice, and this change also was evident only on high magnification (Fig. 1A and B). The enhanced intensity of $\beta$-Syn IR decreased at 9 weeks post injury, and by 16 weeks post injury, it was identical to the normal staining pattern (Fig. 1B); but infrequent $\beta$-Syn IR axonal spheroids were seen in axons of the corpus callosum and internal capsule (Fig. 1B, inset).
Scant $\gamma$-Syn $(\gamma-1)$ IR was seen in the brains of sham mice, but it was induced by $\mathrm{CCI}$ in the corticofugal axons of the striatum at 1-9 weeks post injury (Fig. 1A and B). It then diminished to normal levels by 16 weeks post injury. Infrequent $\gamma$-Syn IR spheroids were seen in axons of the internal capsule and corpus callosum at 9 and 16 weeks post injury (Fig. 1B, inset).

\section{Conformational/nitrative $\alpha$-Syn alterations in aged mouse brains induced by TBI}

Antibodies that recognize conformational (Syn303, Syn505, Syn506, and Syn514) and or nitrative (nSyn14) alterations of $\alpha$-Syn showed no IR in the sham-treated mouse brain; but in the CCI-treated mice, these same antibodies produced increased IR at 1 week post injury restricted exclusively to the cortex near the injury site as well as axon bundles of the striatum, corpus callosum, globus pallidus, and the fimbria of brain ipsilateral to the site of CCI (Fig. 2A-C and Fig. 3). Double FIHC with Syn303 and NFL antibodies (Fig. 2C) showed that Syn303 IR colocalized with a subset of NFL-positive fibrous elements, while double FIHC using Syn303 and LN-39 antibodies revealed $\alpha$-Syn IR colocalized with APP IR in damaged axons (Fig. $2 \mathrm{D})$. The induction of conformational/nitrative alterations in $\alpha$-Syn IR was noted only at 1 week post injury since this IR was markedly reduced or undetectable by 9 weeks post injury and beyond (Fig. 2A and B). Moreover, these transient alterations were most prominent in 24-month-old compared to 4-month-old CCI-treated mice (Fig. 3). IHC revealed that inducible nitric oxide synthase (iNOS) IR appeared in those areas of the old but not young CCI-treated mouse brains that contained conformational/nitratively altered $\alpha$-Syn IR at 1 week post injury (Fig. 3), which suggests that iNOS induction may be linked to the abnormal transient nitration of $\alpha$-Syn in damaged axons.

Despite that this $\alpha$-Syn axonal pathology was most prominent in the 24-month-old CCI-treated mice, the brains of CCI-treated 4-month-old mice killed at 1 and 5 days post TBI showed IR for nitrated $\alpha$-Syn in cortical neurons near the impact site (Fig. 4A), but antibodies to conformationally altered epitopes in $\alpha$-Syn did not produce convincing IR (Fig. 4B). Similar staining patterns also were noted in aged mice (data not shown).

Finally, IHC with all of the antibodies against $\alpha$-Syn used in the present study, including antibodies against conformationally and nitratively altered forms of $\alpha$-Syn, failed to demonstrate any IR in aged $\alpha$-Syn KO mice at 1 week post injury (Fig. 5A).

\section{Western blot analyses of aged mouse brain following TBI}

Brains from control or sham-treated WT mice and aged WT mice subjected to TBI that were examined 1 week post CCI showed comparable levels of monomeric $\alpha$-Syn in Western blots of the high-salt and Triton X-100 fractions 
A.
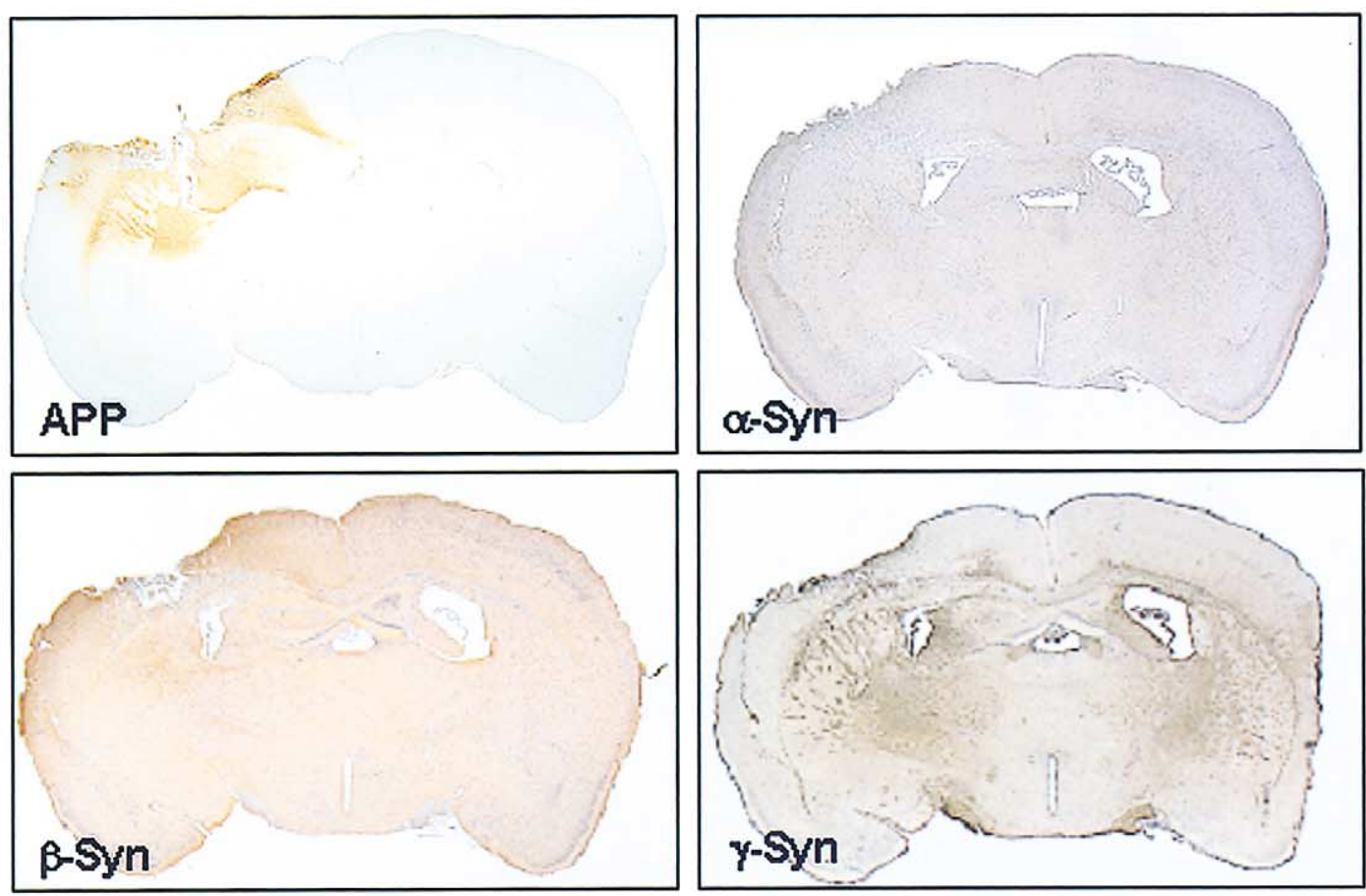

B.
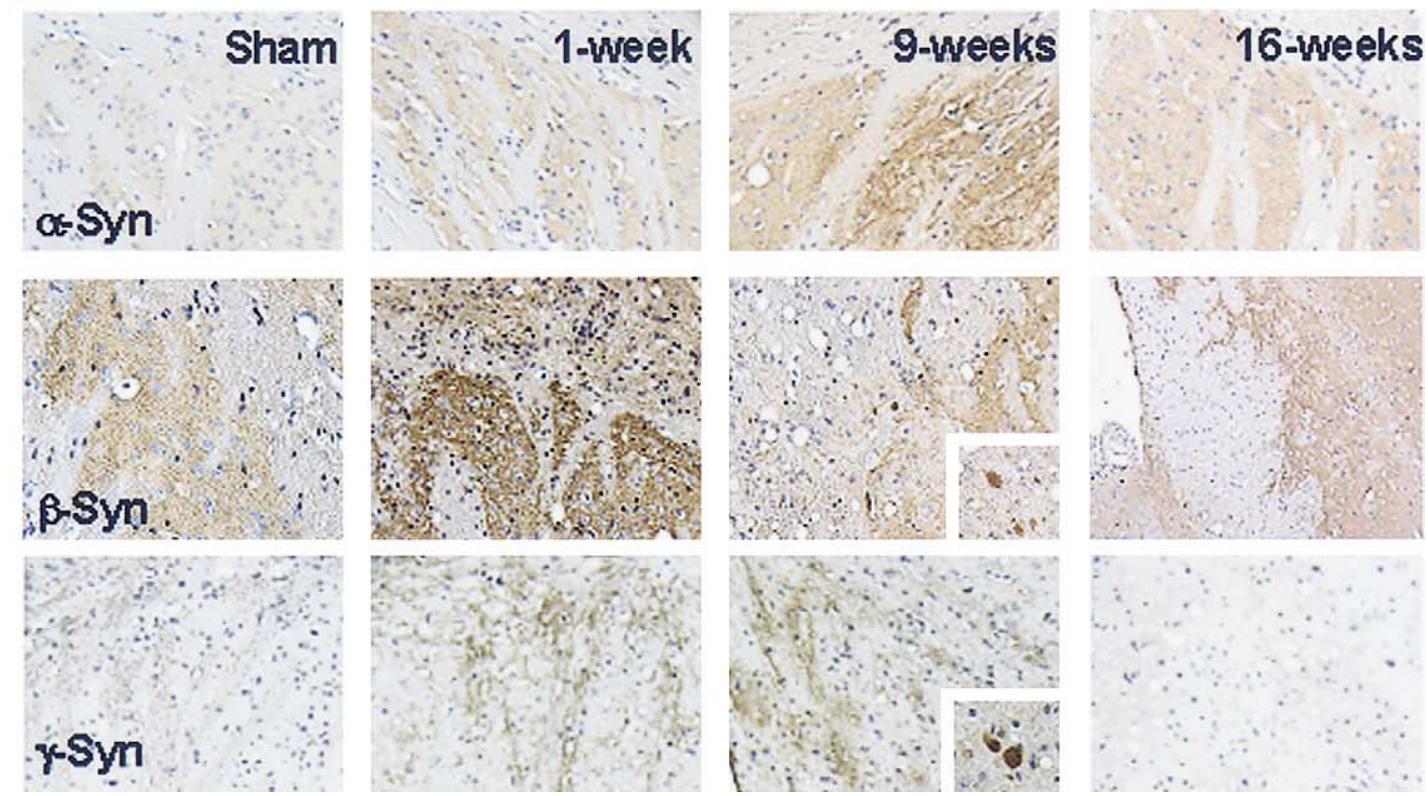

Fig. 1. In the aged wild-type mouse brain, $A \beta$ precursor proteins (APP) immunoreactivity (IR) delineates the damaged area induced by controlled cortical impact (CCI) wherein altered synuclein (Syn) IR also occurs. (A) Low-power views of APP, $\alpha-, \beta$-, and $\gamma$-Syn IR at 1 week post traumatic brain injury (TBI). APP IR identifies the area of CCI-induced damage and antibodies to $\alpha$ - (SNL-1), $\beta$ - (Syn207), and $\gamma$-Syn ( $\gamma$-1) also show variable changes in IR in the same region, but these are more evident when viewed at higher magnification as shown in B using a composite set of images. (B) High-power views of $\alpha$-, $\beta$-, and $\gamma$-Syn IR to at 1, 9, and 16 weeks post TBI in the striatum. At 1 and 9 weeks post TBI, there is an increase axonal IR for $\gamma$-Syn, while only $\alpha$ - and $\beta$-Syn show increased neuropil IR. In addition, antibodies to $\beta$ - and $\gamma$-Syn demonstrate scattered axonal white matter spheroids (inset). In contrast, at 16 weeks post TBI, the changes in Syn IR noted above have decreased to control levels.

(but not the SDS fraction) probed with Syn303 (Fig. 5B). In addition, Syn 303 also recognized murine $\beta$-Syn, and it was evident that the brains from both the sham- and CCI-treated mice also contained similar levels of $\beta$-Syn. However, using the same $\mathrm{mAb}$ and Western blot conditions, the brains from sham- and CCI-treated $\alpha$-Syn KO mouse 1 week post injury 


\section{A. Conformational $-\alpha-$ Syn}
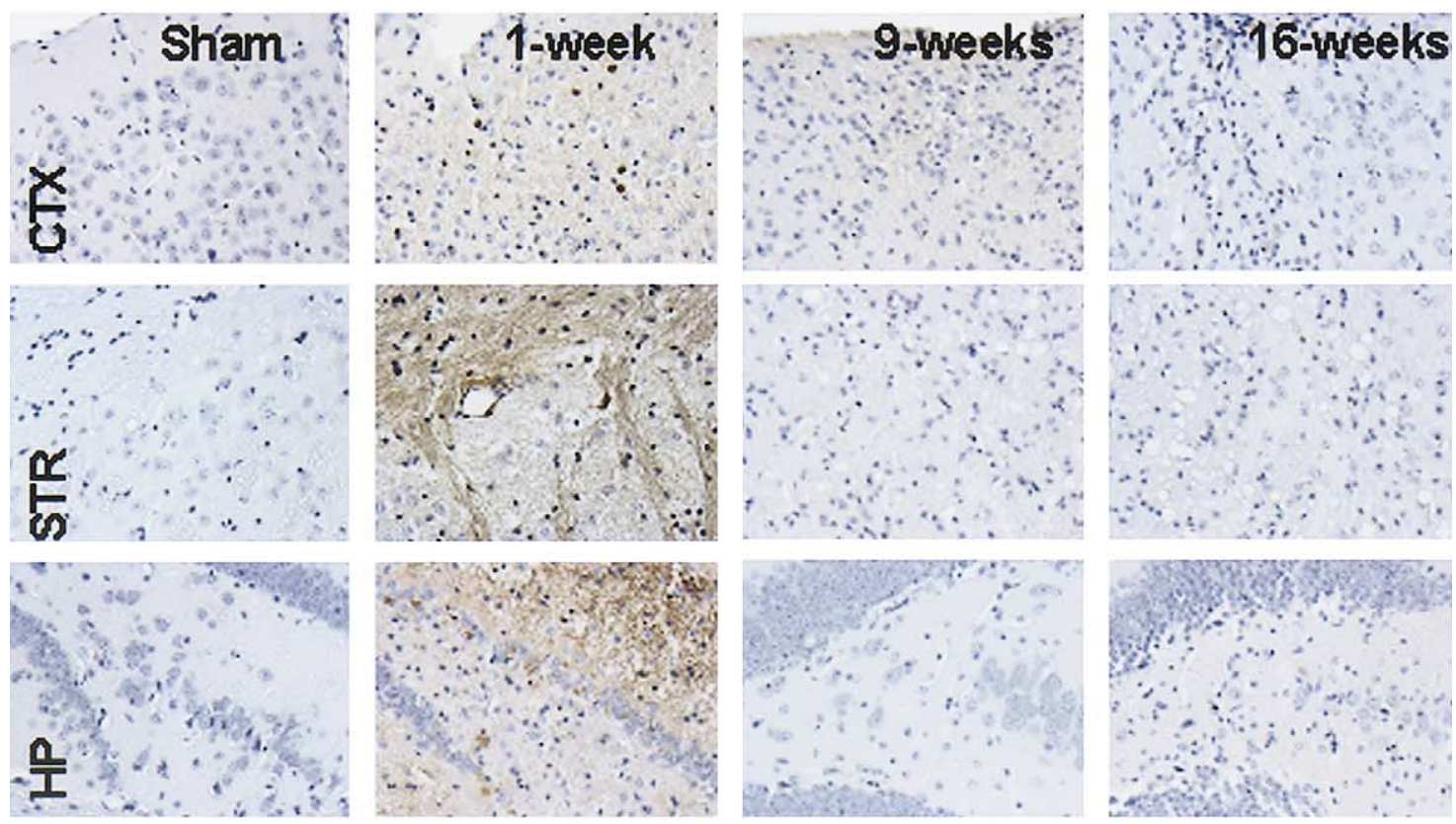

\section{B. Nitrated $\alpha-$ Syn}
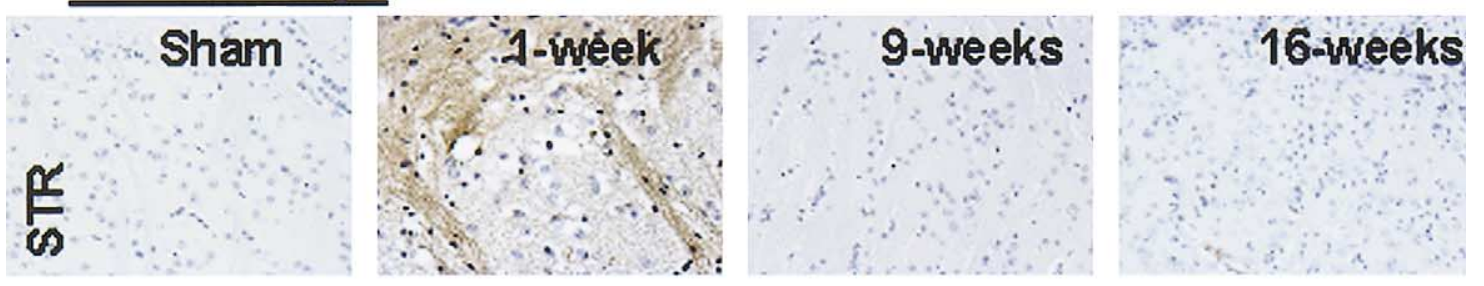

\section{Double FIHC I.}

D. Double FIHC II.
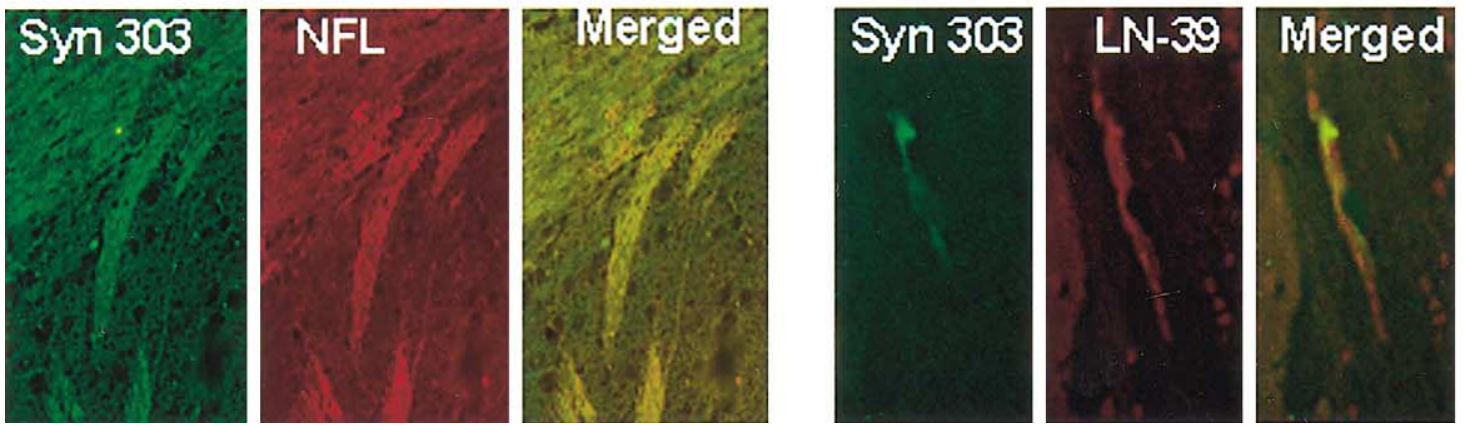

Fig. 2. In the aged mouse brain, $\alpha$-Syn undergoes conformational and nitrative modifications associated with inducible nitric oxide synthase (iNOS) induction following traumatic brain injury (TBI). (A) High-power views of conformationally altered $\alpha$-Syn (Syn303) immunoreactivity (IR) seen mainly at 1 week post TBI in the cortex, striatum, and hippocampus, but not in these same regions at 9 and 16 weeks post TBI or in sham-treated wild-type mice. (B) High-power views of nitrated $\alpha$-Syn (nSyn14) IR at 1 week post TBI in the striatum, but not at 9 and 16 weeks post TBI. (C and D) High-power images of double fluorescence immunohistochemistry (FIHC) with anti-conformational $\alpha$-Syn (Syn303) and anti-NFL antibodies (C) or $\alpha$-Syn (Syn303) and APP (LN-39) antibodies at 1 week post TBI in the striatum (D). This double FIHC (see merged images) reveals that the abnormal $\alpha$-Syn accumulates in axons in the controlled cortical impact-damaged area of the brain. NFL, low $\mathrm{M}_{\mathrm{r}} \mathrm{NF}$ subunit; APP, A $\beta$ precursor protein.

showed no evidence of authentic monomeric $\alpha$-Syn, although monomeric $\beta$-Syn was detected in the high-salt and Triton X-100 fractions but not in the SDS fraction (Fig. 5B).
Interestingly, 45- and 50-kDa $\mathrm{M}_{\mathrm{r}}$ immunobands were noted in the SDS fraction of the brain from the TBI-treated WT mouse brain (Fig. 5B), but they were not seen in the SDS or 


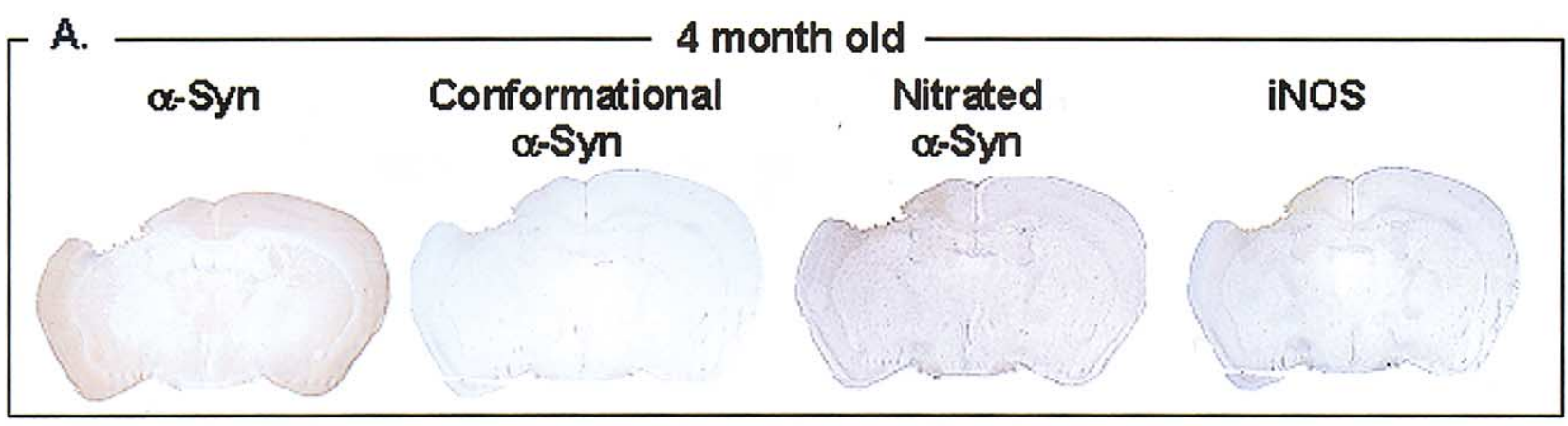

B.

24 month old

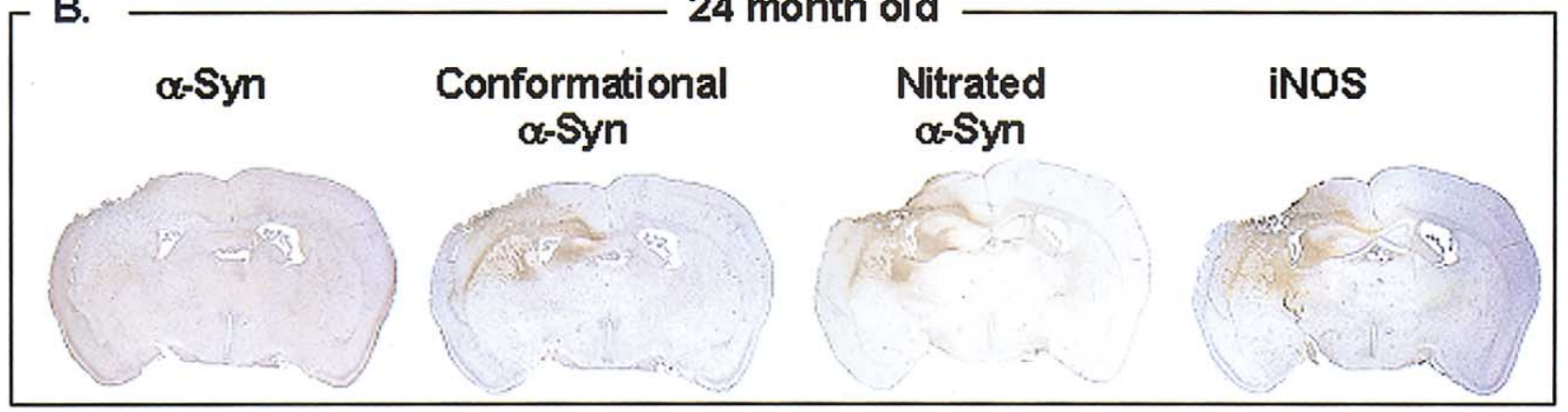

Fig. 3. Comparison of immunoreactivity (IR) for normal $\alpha$-Syn, conformationally altered $\alpha$-Syn, nitrated $\alpha$-Syn, and inducible nitric oxide synthase (iNOS) IR between young and aged wild-type mouse brains at 1 week post traumatic brain injury (TBI). The young (4 month old) mouse brain (A) shows little IR for conformationally altered (Syn303) or nitrated $\alpha$-Syn (nSyn14) nor for iNOS (iNOS-2) at 1 week post TBI, compared to the localized enhanced IR for these proteins in the aged mouse brain (B) in the brain region subjacent to the impact site for controlled cortical impact.

A.
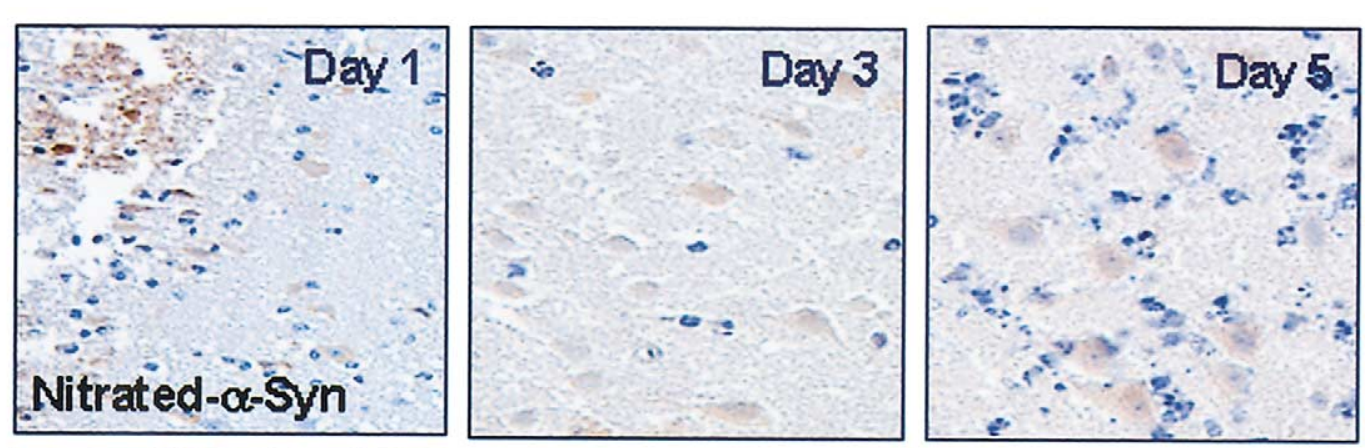

B.
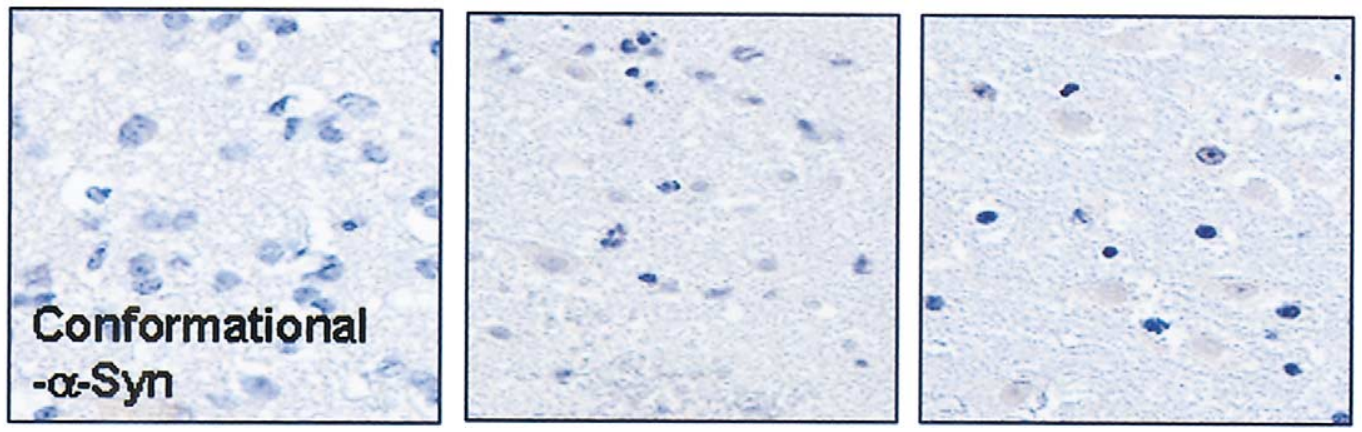

Fig. 4. Limited nitration of $\alpha$-Syn detected in the brains of young wild-type mice following controlled cortical impact (CCI). (A) The young mouse brain shows nitrated $\alpha$-Syn (nSyn14) immunoreactivity (IR) in cortical neurons subjacent to the site of CCI from 1 through 5 days post traumatic brain injury (TBI), whereas this IR diminishes and is no longer detectable at 1 week post TBI. (B) Conformationally altered $\alpha$-Syn (Syn303) IR is not seen in young mice at any time including the times shown in B. 
A.
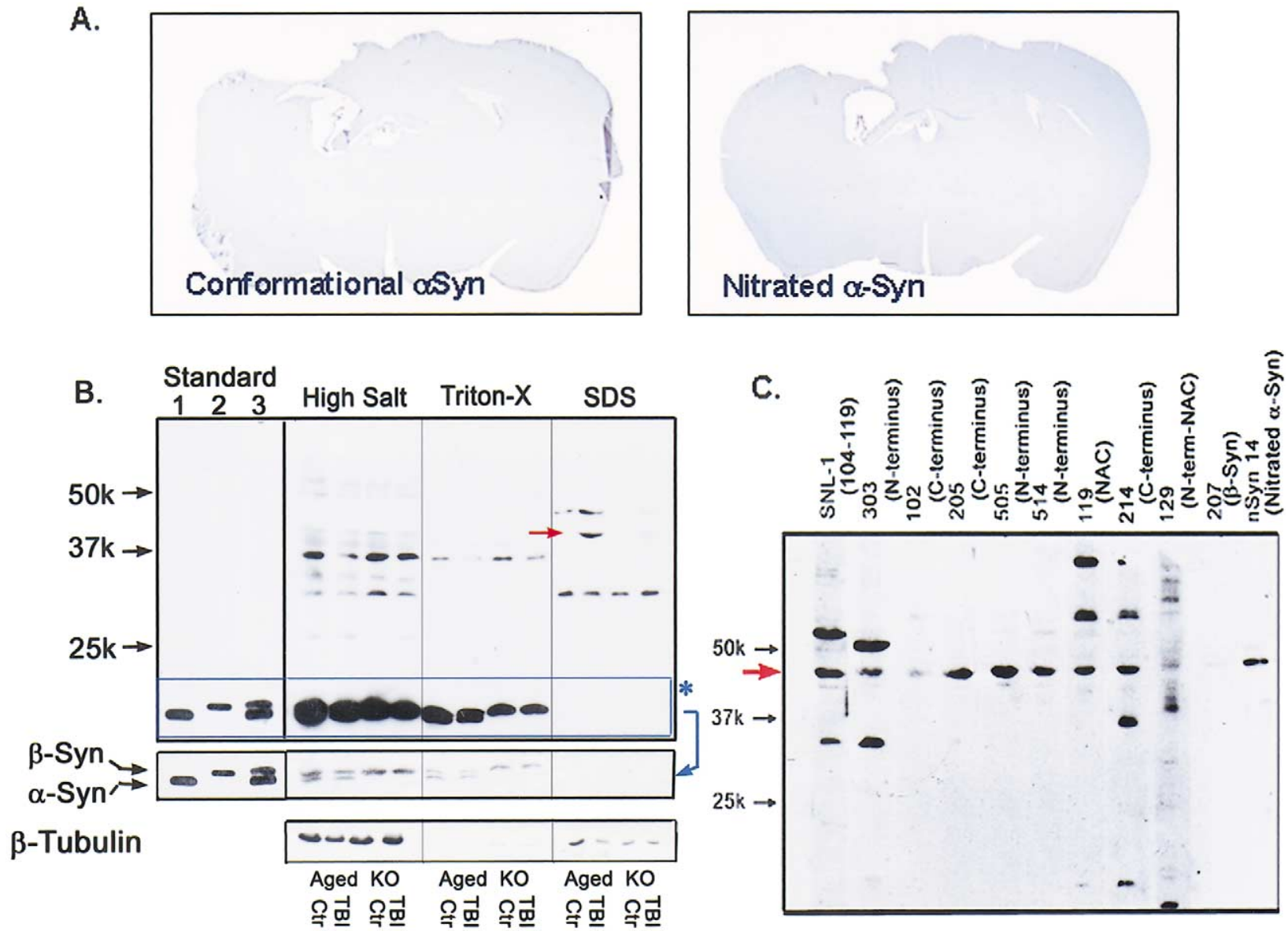

Fig. 5. (A). The aged $\alpha$-Syn knockout (KO) mouse brain shows no $\alpha$-Syn immunoreactivity (IR) following traumatic brain injury (TBI). Immunohistochemistry using antibodies to conformationally altered (Syn303) and nitrated (nSyn14) $\alpha$-Syn shows no IR in the aged $\alpha$-Syn KO mouse at 1 week post TBI, thereby confirming the specificity of the $\alpha$-Syn IR seen in the aged wild-type (WT) mouse brain following TBI. (B and C) Western blot analysis shows a 45-kDa $\mathrm{M}_{\mathrm{r}}$ protein in the insoluble fraction in the aged mouse brain following TBI that is recognized by multiple anti- $\alpha$-Syn antibodies. (B) As molecular standards, $20 \mathrm{ng}$ of recombinant human $\alpha$-Syn (lane 1), $\beta$-Syn (lane 2), or $\alpha$ - and $\beta$-Syn (lane 3) were loaded in the far left panel. The high-salt and Triton-X fractions of aged control (Ctr) WT (Aged) and $\alpha$-Syn KO (KO) mice subjected to controlled cortical impact (CCI) (TBI) show equivalent levels of monomeric $\alpha$-Syn, but only the WT mice show monomeric $\alpha$-Syn immunobands that migrate just below the $\beta$-Syn immunobands. This is seen more clearly in the less exposed portion of the same Western blot that is shown in the separate box below the illustration of the entire Western blot identified with an arrow and asterisk as well as arrows pointing to the $\alpha$-Syn and $\beta$-Syn immunobands. Note that only the brain of the CCI-treated WT mouse shows a 45 -kDa immunoband in the sodium dodecyl sulfate (SDS) fraction that is recognized by Syn303 (arrow in B). Samples were also analyzed by Western blotting for the presence of $\beta$-tubulin (bottom panels) as a control for the processing and gel loading of samples. (C) Numerous other anti- $\alpha$-Syn antibodies, including those that recognize epitopes extending from the N-terminus to the C-terminus of $\alpha$-Syn and nitrated $\alpha$-Syn also consistently detect the same $45-\mathrm{kDa}$ immunoband in the SDS fraction from the brain of the CCI-treated WT mouse, but this band is not detected by an anti- $\beta$-Syn (207) antibody.

any of the other fractions of the brains from the shamtreated WT mouse or the $\alpha$-Syn KO mice. Since either or both of these bands could represent the transiently modified species of $\alpha$-Syn induced by CCI that were detected by IHC, as described above, we examined these immunobands further.

Briefly, the SDS fractions of brain from the TBI-treated aged WT mice at 1 week post CCI were subjected to Western blot analysis with multiple additional antibodies to different $\alpha$-Syn epitopes including those in the C-terminal (SNL-1, Syn102, Syn205, Syn214), central ("NAC"). (Syn119, Syn129), and N-terminal (Syn303, Syn505, Syn506, Syn514) domains of $\alpha$-Syn as well as to nitrated epitopes (including Tyr39) in $\alpha$-Syn (nSyn14) and with an antibody to $\beta$-Syn (Syn 207). Notably, all of the antibodies specific for epitopes in $\alpha$-Syn consistently recognized a 45-kDa immunoband (Fig. 5C) that was not detected by the anti- $\beta$-Syn antibody and therefore probably corresponds to the transiently modified species of $\alpha$-Syn induced by TBI in the aged WT mice. Although some of these anti- $\alpha$-Syn antibodies inconsistently detected other higher and lower $\mathrm{M}_{\mathrm{r}}$ protein bands (data not shown), they do not appear to be reproducible products of TBI-induced modifications in $\alpha$-Syn because they were not recognized consistently by the entire panel of anti- $\alpha$-Syn antibodies as was the case for the 45-kDa band described above. 


\section{Discussion}

Here we show that TBI induced by the CCI paradigm transiently altered the distribution of $\alpha$-Syn, and post-translationally modified this synaptic protein in a unique manner, but only in the aged (24 month old) WT mouse brain and not in young (4 month old) WT mice. Significantly, these changes in $\alpha$-Syn IR in the brains of old WT mice subjected to CCI recapitulate some of the key features of $\alpha$-Syn pathologies that are seen in the brains of patients with synucleiopathies such as accumulations of $\alpha$-Syn in axons, and the generation of nitratively as well as conformationally modified forms of $\alpha$-Syn. Further, similar to authentic human synucleinopathies, these transient modifications and alterations of $\alpha$-Syn were specific largely for this member of the synuclein family of synaptic proteins since more modest transient increases in IR for $\beta$ - and $\gamma$-Syn were detected by IHC in brain sections with antibodies to each of these other members of this family of proteins.

Since Braak and coworkers recently demonstrated that the presence of axonal $\alpha$-Syn pathology in the brainstem of patients with PD is one of the initial morphological manifestations of disease (Braak et al., 1999, 2003) and Duda and his colleagues reported an unprecedented as well as extensive burden of $\alpha$-Syn pathology in the striatum of the brains of patients with different LB disorders (i.e., PD, dementia with LBs or DLB, and AD plus DLB) (Duda et al., 2002), it is plausible to consider that the axonal deposits of $\alpha$-Syn as filamentous inclusions or nonfilamentous aggregates are more significant mediators of neurological and behavioral impairments than LBs themselves in synucleinopathies, especially since the abundance of LBs does not always correlate robustly with such impairments (Hurtig et al., 2000). Thus, our studies here showing an intra-axonal localization of pathological $\alpha$-Syn in the striatum of aged mouse brains following TBI using double FIHC with a combination of antibodies to $\alpha$-Syn and either NFL or APP may facilitate efforts to dissect out the biological significance and underlying mechanisms of axonal $\alpha$-Syn pathologies.

Comparison of the IHC and Western blot data here suggests that TBI induced a nitrative and conformational modification of $\alpha$-Syn, especially in striatal axons, and the 45-kDa immunoband illustrated in Fig. 5C is likely to correspond to this transiently altered form of $\alpha$-Syn microscopic pathology since it was recognized by multiple different antibodies to diverse $\alpha$-Syn epitopes throughout the $\mathrm{N}$-terminal to C-terminal extent of $\alpha$-Syn as well as by antibodies that recognize nitrated and conformationally modified forms of this synaptic protein. In contrast, this $45-\mathrm{kDa}$ protein was not recognized by antibodies specific for $\beta$-Syn. Although the relationship of this $45-\mathrm{kDa}$ protein to different species $\alpha$-Syn is not entirely clear, a recent report described the induction of a similar $45-\mathrm{kDa} \alpha$-Syn-- like protein in PC12 cells treated with nerve growth factor (NGF) for 1 week (Stefanis et al., 2001), and since TBI induces neurotrophin upregulation (DeKosky et al., 1994), it is possible that generation of this $45-\mathrm{kDa}$ protein from monomeric $\alpha$-Syn is a consequence of TBI mediated by neurotrophins. Alternatively, this TBI-induced $\alpha$-Syn-like protein may reflect the formation of a protein complex that results from the interaction of $\alpha$-Syn with itself or with other protein(s) since there is evidence that $\alpha$-Syn itself may function as chaperone that interacts with other proteins (Souza et al., 2000b).

Since it has been shown that nitration of $\alpha$-Syn is a common feature of pathological forms of this protein in LBs of diverse synucleinopathies (Giasson et al., 2000a), it is significant that similar changes were transiently seen following CCI here in aged WT mice because it is known that TBI causes oxidative and nitrative stress (Clark et al., 2001; Liu et al., 2002), including in WT rodents (Semchuk et al., 1992) as well as in transgenic mouse models of AD-like amyloidosis (Uryu et al., 2002). Further, the induction of iNOS closely coincided with the temporal appearance of nitrated $\alpha$-Syn in the brains of CCI-treated WT mice here, and this suggests that TBI-induced iNOS may play a role in transiently modifying the properties of $\alpha$-Syn following TBI. Although it is unclear how nitrative stress contributes to the development of $\alpha$-Syn pathology in human neurodegenerative diseases or TBI, previous studies suggest that oxidative/nitrative stress may play a role in the aggregation of $\alpha$-Syn (Paxinou et al., 2001; Norris et al., 2003) or in stabilizing aggregated forms of $\alpha$-Syn (Souza et al., 2000a). Thus, the data presented here suggest a possible link between TBI, oxidative/nitrative stress, and the generation of $\alpha$-Syn pathology. Finally, the prominence of the enhanced $\alpha$-Syn and $\beta$-Syn IR in axons and the neuropil at $1-9$ weeks following TBI probably reflects a transient perturbation of axonal transport that leads to the accumulation of multiple organelles and proteins followed by the partial or complete reversal of impaired transport and diminution of the abnormal axonal $\alpha$-Syn and $\beta$-Syn IR. Indeed, although the role that altered axonal transport plays in TBI and neurodegeneration is unclear, there is growing evidence to implicate perturbations of axonal transport in these disease processes. However, in selected at-risk individuals, these changes may not be completely reversed thereby predisposing these victims of head trauma to develop AD or PD many years after the initial episode of TBI. While the precise nature of the events that unfold over many years to link one or more episodes of TBI to a greater risk for developing neurological impairments is unclear, further investigations of experimental animal models of TBI such as those described here and transgenic $\alpha$-Syn mice offer a tractable strategy for elucidating how TBI-induced pathological modifications of $\alpha$-Syn contribute to chronic neurodegeneration and behavioral impairments. 


\section{Acknowledgments}

The authors thank Dr. Abeliovich for the gift of the $\alpha$-Syn KO mouse. We also thank our colleagues at the Center for Neurodegenerative Disease Research and the Head Trauma Center for assistance and advice in the studies described here. This work was supported by grants from the National Institutes of Health (National Institute on Aging [AG-09215] and National Institute of Neurological Disorders and Stroke [NS-08803]), the National Football League Charities, and Veteran Administrative Health Science.

\section{References}

Abeliovich, A., Schmitz, Y., Farinas, I., Choi-Lundberg, D., Ho, W.H., Castillo, P.E., Shinsky, N., Verdugo, J.M., Armanini, M., Ryan, A., Hynes, M., Phillips, H., Sulzer, D., Rosenthal, A., 2000. Mice lacking alpha-synuclein display functional deficits in the nigrostriatal dopamine system. Neuron 25, 239-252.

Arawaka, S., Saito, Y., Murayama, S., Mori, H., 1998. Lewy body in neurodegeneration with brain iron accumulation type 1 is immunoreactive for alpha-synuclein. Neurology 51, 887-889.

Arima, K., Ueda, K., Sunohara, N., Hirai, S., Izumiyama, Y., TonozukaUehara, H., Kawai, M., 1998. Immunoelectron-microscopic demonstration of NACP/alpha-synuclein-epitopes on the filamentous component of Lewy bodies in Parkinson's disease and in dementia with Lewy bodies. Brain Res. 808, 93-100.

Auluck, P.K., Chan, E., Trojanoswki, J.Q., Lee, V.M.Y., Bonini, N.M., 2002. Chaperon suppression of $\alpha$-synuclein toxicity in a Drosophila model of Parkinson's disease. Science 295, 865-868.

Baba, M., Nakajo, S., Tu, P.H., Tomita, T., Nakaya, K., Lee, V.M.Y., Trojanowski, J.Q., Iwatsubo, T., 1998. Aggregation of alpha-synuclein in Lewy bodies of sporadic Parkinson's disease and dementia with Lewy bodies. Am. J. Pathol. 152, 879-884.

Betarbet, R., Sherer, T.B., MacKenzie, G., Garcia-Osuna, M., Panov, A.V., Greenamyre, J.T., 2000. Chronic systemic pesticide exposure reproduces features of Parkinson's disease. Nat. Neurosci. 3, 1301-1306.

Braak, H., Del Tredici, K., Rub, U., de Vos, R.A., Jansen Steur, E.N., Braak, E., 2003. Staging of brain pathology related to sporadic Parkinson's disease. Neurobiol. Aging 24, 197-211.

Braak, H., Sandmann-Keil, D., Gai, W., Braak, E., 1999. Extensive axonal Lewy neurites in Parkinson's disease: a novel pathological feature revealed by alpha-synuclein immunocytochemistry. Neurosci. Lett. $265,67-69$.

Clark, R.S.B., Chen, M., Kochanek, P.M., Watkins, S.C., Jin, K.L., Draviam, R., Nathaniel, P.D., Pinto, R., Marion, D.W., Graham, S.H., 2001. Detection of single- and double-strand DNA breaks after traumatic brain injury in rats: comparison of in situ labeling techniques using DNA polymerase I, the Klenow fragment of DNA polymerase I, and terminal deoxynucleotidyl transferase. J. Neurotrauma 18, 675689.

Conway, K.A., Harper, J.D., Lansbury, P.T., 1998. Accelerated in vitro fibril formation by a mutant alpha-synuclein linked to early-onset Parkinson disease. Nat. Med. 4, 1318-1320.

DeKosky, S.T., Goss, J.R., Miller, P.D., Styren, S.D., Kochanek, P.M., Marion, D., 1994. Upregulation of nerve growth factor following cortical trauma. Exp. Neurol. 130, 173-177.

Duda, J.E., Giasson, B.I., Mabon, M.E., Lee, V.M.Y., Trojanowski, J.Q. 2002. Novel antibodies to synuclein show abundant striatal pathology in Lewy body diseases. Ann. Neurol. 52, 205-210.

Factor, S.A., Weiner, W.J., 1991. Prior history of head trauma in Parkinson's disease. Mov Disord. 6, 225-229.
Feany, M.B., Bender, W.W., 2000. A Drosophila model of Parkinson's disease. Nature 404, 394-398.

Fujiwara, H., Hasegawa, M., Dohmae, N., Kawashima, A., Masliah, E., Goldberg, M.S., Shen, J., Takio, K., Iwatsubo, T., 2002. $\alpha$-Synuclein is phosphorylated in synucleinopathy lesions. Nat. Cell Biol. 4, 160-164.

Giasson, B.I., Duda, J.E., Forman, M.S., Lee, V.M.Y., Trojanoswki, J.Q., 2001. Prominent perikaryal expression of $\alpha$ - and $\beta$-synuclein in neurons of dorsal root ganglion and in medullary neurons. Exp. Neurol. $172,354-362$.

Giasson, B.I., Duda, J.E., Murray, I.V., Chen, Q., Souza, J.M., Hurtig, H.I., Ischiropoulos, H., Trojanowski, J.Q., Lee, V.M.Y., 2000a. Oxidative damage linked to neurodegeneration by selective alpha-synuclein nitration in synucleinopathy lesions. Science 290, 985-989.

Giasson, B.I., Jakes, R., Goedert, M., Duda, J.E., Leight, S., Trojanowski, J.Q., Lee, V.M.Y., 2000b. A panel of epitope-specific antibodies detects protein domains distributed throughout human alpha-synuclein in Lewy bodies of Parkinson's disease. J. Neurosci. Res. 59, 528-533.

Hubble, J.P., Cao, T., Hassanein, R.E., Neuberger, J.S., Koller, W.C., 1993. Risk factors for Parkinson's disease. Neurology 43, 1693-1697.

Hurtig, H.I., Trojanowski, J.Q., Galvin, J., Ewbank, D., Schmidt, M.L., Lee, V.M.Y., Clark, C.M., Glosser, G., Stern, M.B., Gollomp, S.M., Arnold, S.E., 2000. Alpha-synuclein cortical Lewy bodies correlate with dementia in Parkinson's disease. Neurology 54, 1916-1921.

Irizarry, M.C., Growdon, W., Gomez-Isla, T., Newell, K., George, J.M., Clayton, D.F., Hyman, B.T., 1998. Nigral and cortical Lewy bodies and dystrophic nigral neurites in Parkinson's disease and cortical Lewy body disease contain alpha-synuclein immunoreactivity. J. Neuropathol. Exp. Neurol. 57, 334-337.

Ishihara, T., Hong, M., Zhang, B., Nakagawa, Y., Lee, M.K., Trojanowski, J.Q., Lee, V.M.Y., 1999. Age-dependent emergence and progression of a tauopathy in transgenic mice overexpressing the shortest human tau isoform. Neuron 24, 751-762.

Kruger, R., Kuhn, W., Muller, T., Woitalla, D., Graeber, M., Kosel, S., Przuntek, H., Epplen, J.T., Schols, L., Riess, O., 1998. Ala30Pro mutation in the gene encoding alpha-synuclein in Parkinson's disease. Nat. Genet. 18, 106-108.

Langston, J.W., Ballard, P., Tetrud, J.W., Irwin, I., 1983. Chronic parkinsonism in humans due to a product of meperidine-analog synthesis. Science 219, 979-980.

Liu, P.K., Robertson, C.S., Valadka, A., 2002. The association between neuronal nitric oxide synthase and neuronal sensitivity in the brain after brain injury. Ann. N. Y. Acad. Sci. 962, 226-241.

Masliah, E., Rockenstein, E., Veinbergs, I., Mallory, M., Hashimoto, M., Takeda, A., Sagara, Y., Sisk, A., Mucke, L., 2000. Dopaminergic loss and inclusion body formation in alpha-synuclein mice: implications for neurodegenerative disorders. Science 287, 1265-1269.

Maxwell, W.L., Povlishock, J.T., Graham, D.L., 1997. A mechanistic analysis of nondisruptive axonal injury: a review. J. Neurotrauma 14 , 419-440.

McIntosh, T.K., Saatman, K.E., Raghupathi, R., Graham, D.I., Smith, D.H., Lee, V.M.Y., Trojanowski, J.Q., 1998. The Dorothy Russell Memorial Lecture. The molecular and cellular sequelae of experimental traumatic brain injury: pathogenetic mechanisms. Neuropathol. Appl. Neurobiol. 24, 251-267.

Mesenge, C., Charriaut-Marlangue, C., Verrecchia, C., Allix, M., Boulu, R.R., Plotkine, M., 1998. Reduction of tyrosine nitration after N(omega)nitro-L-arginine- methylester treatment of mice with traumatic brain injury. Eur. J. Pharmacol. 353, 53-57.

Murai, H., Pierce, J.E., Raghupathi, R., Smith, D.H., Saatman, K.E., Trojanowski, J.Q., Lee, V.M.Y., Loring, J.F., Eckman, C., Younkin, S., McIntosh, T.K., 1998. Twofold overexpression of human beta-amyloid precursor proteins in transgenic mice does not affect the neuromotor, cognitive, or neurodegenerative sequelae following experimental brain injury. J. Comp Neurol. 392, 428-438.

Nakagawa, Y., Nakamura, M., McIntosh, T.K., Rodriguez, A., Berlin, J.A., Smith, D.H., Saatman, K.E., Raghupathi, R., Clemens, J., Saido, T.C., Schmidt, M.L., Lee, V.M.Y., Trojanowski, J.Q., 1999. Traumatic brain 
injury in young, amyloid-beta peptide overexpressing transgenic mice induces marked ipsilateral hippocampal atrophy and diminished Abeta deposition during aging. J. Comp Neurol. 411, 390-398.

Nakagawa, Y., Reed, L., Nakamura, M., McIntosh, T.K., Smith, D.H., Saatman, K.E., Raghupathi, R., Clemens, J., Saido, T.C., Lee, V.M.Y., Trojanowski, J.Q., 2000. Brain trauma in aged transgenic mice induces regression of established a-beta deposits. Exp. Neurol. 163, 244-252.

Nayernouri, T., 1985. Posttraumatic parkinsonism. Surg. Neurol. 24, 263 264.

Newell, K.L., Boyer, P., Gomez-Tortosa, E., Hobbs, W., Hedley-Whyte, E.T., Vonsattel, J.P., Hyman, B.T., 1999. Alpha-synuclein immunoreactivity is present in axonal swellings in neuroaxonal dystrophy and acute traumatic brain injury. J. Neuropathol. Exp. Neurol. 58, 12631268.

Norris, E.H., Giasson, B.I., Ischiropoulos, H., Lee, V.M.Y., 2003. Effects of oxidative and nitrative challenges on alpha -synuclein fibrillogenesis involve distinct mechanisms of protein modifications. Journal of Biological Chemistry, (In press).

Paxinou, E., Chen, Q., Weisse, M., Giasson, B.I., Norris, E.H., Rueter, S.M., Trojanowski, J.Q., Lee, V.M.Y., Ischiropoulos, H., 2001. Induction of alpha-synuclein aggregation by intracellular nitrative insult. J. Neurosci. 21, 8053-8061.

Perry, E.K., Haroutunian, V., Davis, K.L., Levy, R., Lantos, P., Eagger, S., Honavar, M., Dean, A., Griffiths, M., McKeith, I.G., 1994. Neocortical cholinergic activities differentiate Lewy body dementia from classical Alzheimer's disease. Neuroreport 5, 747-749.

Pierce, J.E., Smith, D.H., Trojanowski, J.Q., McIntosh, T.K., 1998. Enduring cognitive, neurobehavioral and histopathological changes persist for up to one year following severe experimental brain injury in rats. Neuroscience 87, 359-369.

Polymeropoulos, M.H., Lavedan, C., Leroy, E., Ide, S.E., Dehejia, A., Dutra, A., Pike, B., Root, H., Rubenstein, J., Boyer, R., Stenroos, E.S., Chandrasekharappa, S., Athanassiadou, A., Papapetropoulos, T., Johnson, W.G., Lazzarini, A.M., Duvoisin, R.C., Di Iorio, G., Golbe, L.I., Nussbaum, R.L., 1997. Mutation in the alpha-synuclein gene identified in families with Parkinson's disease. Science 276, 2045-2047.

Pratico, D., Reiss, P., Tang, L.X., Sung, S., Rokach, J., McIntosh, T.K., 2002. Local and systemic increase in lipid peroxidation after moderate experimental traumatic brain injury. J. Neurochem. 80, 894-898.

Przedborski, S., Jackson-Lewis, V., 1998. Mechanisms of MPTP toxicity. Mov. Disord. 13 (Suppl. 1), 35-38.

Romijn, H.J., van Uum, J.F., Breedijk, I., Emmering, J., Radu, I., Pool, C.W., 1999. Double immunolabeling of neuropeptides in the human hypothalamus as analyzed by confocal laser scanning fluorescence microscopy. J. Histochem. Cytochem. 47, 229-236.

Souza, J.M., Giasson, B.I., Chen, Q., Lee, V.M.Y., Ischiropoulos, H., 2000a. Dityrosine cross-linking promotes formation of stable alphasynuclein polymers. Implication of nitrative and oxidative stress in the pathogenesis of neurodegenerative synucleinopathies. J. Biol. Chem. $275,18344-18349$.

Souza, J.M., Giasson, B.I., Lee, V.M.Y., Ischiropoulos, H., 2000b. Chaperone-like activity of synucleins. FEBS Lett. 474, 116-119.

Spillantini, M.G., Crowther, R.A., Jakes, R., Hasegawa, M., Goedert, M., 1998. Alpha-synuclein in filamentous inclusions of Lewy bodies from Parkinson's disease and dementia with Lewy bodies. Proc. Natl. Acad. Sci. USA 95, 6469-6473.

Spillantini, M.G., Schmidt, M.L., Lee, V.M.Y., Trojanowski, J.Q., Jakes, R., Goedert, M., 1997. Alpha-synuclein in Lewy bodies. Nature 388, 839-840.

Stefanis, L., Kholodilov, N., Rideout, H.J., Burke, R.E., Greene, L.A., 2001. Synuclein-1 is selectively up-regulated in response to nerve growth factor treatment in PC12 cells. J. Neurochem. 76, 1165-1176.

Stern, M.B., 1991. Head trauma as a risk factor for Parkinson's disease. Mov Disord. 6, 95-97.

Tanner, C.M., Chen, B., Wang, W., Peng, M., Liu, Z., Liang, X., Kao, L.C., Gilley, D.W., Goetz, C.G., Schoenberg, B.S., 1989. Environmental factors and Parkinson's disease: a case-control study in China. Neurology 39, 660-664.

Tanner, C.M., Ottman, R., Goldman, S.M., Ellenberg, J., Chan, P., Mayeux, R., Langston, J.W., 1999. Parkinson disease in twins: an etiologic study. JAMA 281, 341-346.

Trojanowski, J.Q., Lee, V.M.Y., 2002. Parkinson's disease and related synucleinopathies are a new class of nervous system amyloidoses. Neurotoxicology 23, 457-460.

Tu, P.H., Galvin, J.E., Baba, M., Giasson, B., Tomita, T., Leight, S., Nakajo, S., Iwatsubo, T., Trojanowski, J.Q., Lee, V.M.Y., 1998. Glial cytoplasmic inclusions in white matter oligodendrocytes of multiple system atrophy brains contain insoluble alpha-synuclein. Ann. Neurol. $44,415-422$.

Uryu, K., Laurer, H., McIntosh, T., Pratico, D., Martinez, D., Leight, S., Lee, V.M.Y., Trojanowski, J.Q., 2002. Repetitive mild brain trauma accelerates Abeta deposition, lipid peroxidation, and cognitive impairment in a transgenic mouse model of Alzheimer amyloidosis. J. Neurosci. 22, 446-454. 